\title{
Retraction
}

\section{Retracted: Ghanaians Might Be at Risk of Inadequate Dietary Intake of Potassium}

\section{Journal of Nutrition and Metabolism}

Received 13 June 2017; Accepted 13 June 2017; Published 12 July 2017

Copyright (C) 2017 Journal of Nutrition and Metabolism. This is an open access article distributed under the Creative Commons Attribution License, which permits unrestricted use, distribution, and reproduction in any medium, provided the original work is properly cited.

Journal of Nutrition and Metabolism has retracted the article titled "Ghanaians Might Be at Risk of Inadequate Dietary Intake of Potassium" [1]. The authors have noted that the potassium values should have been multiplied by 10 , and this will substantially alter the conclusion of the article.

\section{References}

[1] D. O. Yawson, M. O. Adu, B. Ason, F. A. Armah, E. Boateng, and R. Quansah, "Ghanaians might be at risk of inadequate dietary intake of potassium," Journal of Nutrition and Metabolism, vol. 2016, Article ID 3150498, 8 pages, 2016. 